\title{
TINJAUAN SOSIOLOGI HUKUM TERHADAP PENYALAHGUNAAN NARKOBA DI KALANGAN ANGGOTA LEGISLATIF
}

\author{
“Legal Sociology Review Of Drug Abuse In Legislative Members" \\ Saffa Kirana Masloman, Lidya Ananda Putri, Felina Safitri Niaty \\ Fakultas Hukum, Universitas Negeri Gorontalo \\ Jl. Jend. Sudirman No.6, Dulalowo Tim., Kota Tengah, Kota Gorontalo, Gorontalo 96128 \\ Email: savakirana@yahoo.com
}

\begin{abstract}
Abstrak
Narkotika merupakan zat atau obatan yang berasal dari tanaman maupun bukan tanaman yang memberikan rasa bahagia, tenang, dan rileks bagi para pemakai Narkoba. Penggunaan Narkoba tidak hanya membuat si pengguna kecanduan atau ketergantungan tetapi juga dapat mengakibatkan kematian. Perkembangan Narkoba yang sangat pesat dan dapat menjangkau seluruh kalangan masyarakat tanpa memandang umur, status social, dan jabatan yang dimiliki. Dalam hal memerangi Narkoba perlu adanya kerjasama antara masyarakat dan pemerintah secara intensif. Namun pada saat ini, tidak sedikit juga wakil rakyat atau anggota Legislatif yang terjerat kasus Narkoba. Salah satu faktor anggota Legislative tergiur untuk menggunakan Narkoba dikarenakan stress berat yang di alami oleh anggota Legislative tersebut. Keterlibatan anggota Legislative dalam penyalahgunaan Narkoba mengakibatkan terbengkalainya tugas-tugas seorang wakil rakyat dan kurangnya konsentrasi dalam mengurus permasalah-permasalahan yang ada ditiap-tiap daerah.
\end{abstract}

Kata Kunci: Penyalahgunaan; Narkoba; Anggota Legislatif.

\section{Abstract}

Narcotics are substances or drugs that come from plants or not plants that provide a sense of happiness, calm, and relaxation for drug users. The use of narcotics not only makes the user addicted or addicted but can also lead to death. The development of narcotics is very rapid and can reach all levels of society regardless of age, social status, and position they have. In the case of combating narcotics there needs to be an intensive collaboration between the community and the government. But at this time, not a few are also representatives of the people or members of the Legislature who are entangled in drug cases. One factor Legislative members are tempted to use drugs because of the severe stress experienced by members of the Legislative. The involvement of Legislative members in drug abuse results in the neglect of the duties of a representative of the people and a lack of concentration in taking care of the problems that exist in each region.

Keywords: Abuse; Drugs; Legislative member. 


\section{PENDAHULUAN}

\section{Latar Belakang}

Pada saat ini perkembangan Narkoba di Indonesia meningkat sangat pesat yang juga telah menjangkau berbagai kalangan masyarakat tanpa memandang umur, status social dan jabatan yang dimiliki. Narkotika merupakan zat atau obatan yang berasal dari tanaman maupun bukan tanaman yang memberikan rasa bahagia, tenang, dan rileks bagi para pemakai Narkoba. Penggunaan Narkoba tidak hanya membuat si pengguna kecanduan atau ketergantungan tetapi juga dapat mengakibatkan kematian. Pesatnya perkembangan Narkoba di Indonesia dipengaruhi dari kurangnya sikap intensif dari para penegak hukum dalam penanggulangan Narkoba. Menurut Kepala Badan Narkotika Nasional (BNN) Komjen Pol Heru Winarko mengatakan jenis Narkoba yang mendominasi di Indonesia adalah ganja yang mencapai 63 persen dari total peredaran Narkoba di Indonesia. Juga kepala BNN mengatakan bahwa ada kenaikan 0,03 persen peredaran Narkoba tahun 2019 dan lebih kurang ada 3,6 juta orang yang menggunakan Narkoba di Indonesia.

Dalam Pasal 7 Undang-Undang No. 35 Tahun 2009 tentang Narkotika berbunyi "Narkotika hanya dapat digunakan untuk kepentingan pelayanan kesehatan dan/atau pengembangan ilmu pengetahuan dan teknologi". 'Merujuk pada pasal tersebut, yang terjadi saat ini pemakaian Narkoba telah banyak disalah gunakan. Narkoba bukan lagi sebagai pengobatan atau pengembangan ilmu pengetahuan melainkan digunakan sebagai alat untuk kepuasan diri sendiri agar merasa bahagia, tenang, dan rileks. Narkoba yang di gunakan dalam dosis yang tinggi dan tidak sesuai oleh anjuran dokter dapat mengakibatkan si pemakai mabuk kemudian berujung pada ketergantungan. Dalam hal ini, Narkoba menjadi salah satu bisnis yang menggiurkan dengan keuntungan yang sangat besar karena dapat menjangkau berbagai kalangan masyarakat yang membutuhkan sebuah zat atau obat untuk merasa lebih rileks.

Saat ini jangkauan Narkoba tidak hanya dikalangan masyarakat biasa melainkan sudah merambat masuk dikalangan Anggota Legislatif. Menurut informasi dari Detik.com pada tanggal 22 Maret 2020, ditulis bahwa 2 anggota DPRD Sulawesi ditanggkap akibat penggunaan Narkoba. Dalam artikel lain yaitu Makassar.kompas.com juga menulis bahwa Anggota DPRD Makassar juga ditangkap akibat penggunaan Narkoba. Keterlibatan anggota Legislative dalam penyalahgunaan Narkoba mengakibatkan terbengkalainya tugas-tugas seorang wakil rakyat dan kurangnya konsentrasi dalam mengurus permasalah-permasalahan yang ada ditiaptiap daerah.

Hal ini tentu membuat resah masyarakat karena para wakil rakyat yang seharusnya beperang melawan Narkoba di Indonesia justru banyak terlibat dalam penyalahgunaan Narkoba. Sangat disayangkan, anggota Legislative yang harusnya memberi contoh yang baik untuk masyarakat justru melakukan hal-hal yang tidak sepantasnya dilakukan.

Salah satu faktor anggota Legislative tergiur untuk menggunakan Narkoba dikarenakan stress berat yang di alami oleh anggota Legislative tersebut. Dilain sisi Legislative memiliki fungsi control terhadap penyelenggaraan pemerintahan, oleh karena itu anggota Legislative haruslah orang-orang yang sehat secara jasmani maupun rohani..

\section{Rumusan Masalah}

Kajian ini akan menjawab 2 (dua) pertanyaan sebagai rumusan masalah yaitu bagaimana ketegasan sanksi terhadap penyalahgunaan Narkotika di kalangan

\footnotetext{
1 Pasal 7 Undang-undang No. 35 Tahun 2009
} 
Legislatif? Serta bagaimana Kebijakan kriminal yang dilakukan untuk memberantas penyalah guna narkotika di kalangan legislatif?

\section{Metode Penelitian}

\section{Jenis Penelitian}

Penelitian adalah sebuah cara untuk menemukan jawaban dari pertanyaanpertanyaan dengan menggunakan prosedur yang sistematis dan ilmiah. Kesimpulan hasil penelitian diperoleh berdasarkan temuantemuan dan data empiris. ${ }^{2}$

Metode penelitian pada dasarnya merupakan cara ilmiah untuk mendapatkan data dengan tujuan dan kegunaan tertentu. Untuk mencapai tujuan yang diperlukan dibutuhkan metode yang relevan untuk mencapai tujuan yang diinginkan (Sugiyono, 2016:1) ${ }^{3}$

Penelitian merupakan sarana (ilmiah) bagi pengembangan ilmu pengetahuan dan teknologi, maka metodologi penelitian yang diterapkan harus senantiasa disesuaikan dengan ilmu pengetahuan yang menjadi induknya. Hal ini tidaklah selalu berarti metodologi penelitian yang dipergunakan pelbagai ilmu pengetahuan pasti akan berbeda secara utuh. Akan tetapi setiap ilmu pengetahuan mempunyai identitas masingmasing, sehingga pasti akan ada pelbagai perbedaan. Demikian juga halnya dengan metodologi penelitian hukum yang mempunyai karakteristik khusus yang menjadi identitasnya, sehingga dapat dibedakan dari ilmu- ilmu pengetahuan lainnya. ${ }^{4}$

Jenis penelitian hukum yang digunakan oleh peneliti dalam menyusun usulan penelitian ini adalah jenis penelitian

2Endang Mulyatiningsih, Metode Penelitian terapan Bidang Pendidikan, CV Alfabeta : Bandung, 2014

3 Bambang Sunggono, 2016, Metodologi Penelitian Hukum, Rajawali Pers, Jakarta, hlm. hukum empiris. Penelitian Hukum Empiris adalah suatu metode penelitian hukum yang menggunakan fakta-fakta empiris yang diambil dari perilaku manusia, baik perilaku verbal yang didapat dari wawancara maupun perilaku nyata yang dilakukan melalui pengamatan langsung. Penelitian empiris juga digunakan untuk mengamati hasil dari perilaku manusia yang berupa peninggalan fisik maupun arsip. ${ }^{5}$

\section{Lokasi Penelitian}

Penelitian ini dilakukan di Kabupaten Boalemo Provinsi Gorontalo, dengan fokus penelitian pada Anggota DPRD Kabupaten Boalemo Provinsi Gorontalo yang menyalahgunakan Narkoba. Pertimbangan mengenai dipilihnya lokasi penelitian ini yaitu dengan melakukan penelitian di lokasi tersebut, yaitu karena belum lama ini terdapat kasus menarik tertangkpanya 2 orang anggota DPRD Kabupaten Boalemo di sebuah diskotek di kawasan Mangga Besar, Jakarta Barat.

\section{Jenis dan Sumber Data}

Pengumpulan data dalam studi pustaka ini dilakukan penelitian dengan cara mempelajari dan mengumpulkan data yang berhubungan dengan objek penelitian. Datadata tersebut diperoleh dari buku-buku kepustakaan, peraturan perundangundangan, browsing internet, dan dokumendokumen lainnya. Dalam hal ini peneliti mencari buku-buku yang dibutuhkan. Data sekunder dikelompokkan menjadi 3 jenis bahan hukum, yaitu:

1) Bahan hukum primer Bahan hukum primer adalah bahan hukum yang mengikat atau bahan yang berkait erat

4 Depri Liber Sonata, "Metode Penelitian Hukum Normatif dan Empiris: Karakteristik Khas Dari Metode Meneliti Hukum", jurnal fiat justitia, vol.8, No.1, 2014

5 Mukti Fajar dan Yulianto Achmad, 2010, Dualisme Penelitian Hukum Empiris \& Normatif, Pustaka Pelajar, hlm.280 
dengan permasalahan yang diteliti, meliputi:

a. Undang-undang Dasar Negara Republik Indonesia Tahun 1945.

b. UU no 35 tahun 2009 tentang Narkoba

2) Bahan Hukum Sekunder Bahan hukum sekunder, yaitu memberikan penjelasan mengenai bahan hukum primer, yaitu:

a. Buku-buku yang berkaitan dengan judul dan permasalahan yang akan dikaji dalam penulisan skripsi ini.

b. Hasil penelitian dan karya tulis ilmiah yang berkaitan dengan penulisan skripsi ini.

c. Makalah-makalah seminar terkait dengan penulisan skripsi ini.

d. Jurnal hukum dan literatur yang terkait dengan penulisan skripsi.

3) Bahan Hukum Tersier Bahan hukum tersier yaitu bahan yang memberikan petunjuk atau penjelasan terhadap bahan hukum primer dan bahan hukum sekunder, yaitu:

a. Kamus Hukum

b. Kamus Bahasa Indonesia

c. Kamus Bahasa Inggris

d. Ensiklopedia terkait.

Sumber data dalam penelitian ini adalah Penelitian pustaka (library research), yaitu membaca serta menelaah berbagai literatur seperti buku kepustakaan, koran, dan karya ilmiah yang relevan dan berkaitan langsung dengan obyek penelitian.

\section{Teknik Pengumpulan Data}

Metode pengumpulan data dalam penelitian ini adalah Studi pustaka. Studi pustaka dilakukan untuk mengumpulkan bahan data sekunder, dengan cara mempelajari peraturan hukum dan literatur yang berkaitan dengan narkoba yaitu dengan membaca, mengutip, mencatat dan mengidentifikasi data yang sesuai dengan permasalahan dan pokok bahasan.

6 Pasal 1 angka 15 UU No.35 Tahun 2009

7 Fransiska Novita Eleanora, "Bahaya Penyalahgunaan Narkoba Serta Usaha

\section{Analisis Data}

Bahan hukum (data) hasil pengolahan tersebut dianalisis dengan menggunakan metode analisis secara kualitatif, yaitu menguraikan data secara bermutu dalam bentuk kalimat yang tersusun secara teratur, runtun, logis, tidak tumpang tindih dan efektif.

\section{PEMBAHASAN}

\section{Ketegasan sanksi terhadap penyalahgunaan Narkotika di kalangan Legislatif}

Narkotika merupakan zat atau obatan yang berasal dari tanaman maupun bukan tanaman yang memberikan rasa bahagia, tenang, dan rileks bagi para pemakai Narkoba. Penggunaan Narkoba tidak hanya membuat si pengguna kecanduan atau ketergantungan tetapi juga dapat mengakibatkan kematian. Pesatnya perkembangan Narkoba di Indonesia dipengaruhi dari kurangnya sikap intensif dari para penegak hukum dalam penanggulangan Narkoba.

Adapun yang dimaksud dengan Penyalah Guna adalah orang yang menggunakan narkotika tanpa hak atau melawan hukum. ${ }^{6}$ Saat ini jangkauan Narkoba tidak hanya dikalangan masyarakat biasa melainkan sudah merambat masuk dikalangan Anggota Legislatif. Keterlibatan anggota Legislative dalam Penyalah Guna Narkoba mengakibatkan terbengkalainya tugas-tugas seorang wakil rakyat dan kurangnya konsentrasi dalam mengurus permasalah-permasalahan yang ada ditiaptiap daerah.

Perkembangan Narkoba yang sangat pesat dapat menjangkau semua lapisan masyarakat dari pelajar, mahasiswa, artis, ibu rumah tangga, pedagang, supir angkot, anak jalanan, pekerja, dan lain sebagainya. Narkoba dengan mudahnya diperoleh, bahkan dapat diracik sendiri, pabrik narkoba secara ilegalpun sudah didapati di Indonesia. ${ }^{7}$

Pencegahan dan Penanggulangannya (Suatu Tinjauan Teoritis), FH Universitas MPU Tantular Jakarta 
Bahkan narkoba sendiri sudah menjadi hal biasa dikalangan atas berupa petinggi Negara,pejabat,bahkan Dewan Per-wakilan Rakyat itu sendiri.

Di Indonesia penyalah guna Narkotika merupakan suatu kejahatan luar biasa (extraordinary crime) yang dikendalikan oleh sindikat terorganisir dengan jaringan peredaran yang sangat luas. Penyalah guna narkotika di ataur dalam Undang-Undang No.35 Tahun 2009 dengan pembagian sanksi pidana menurut Pasal 127 ayat 1 yaitu "Setiap penyalah guna Narkotika Golongan I bagi diri sendiri dipidana dengan pidana penjara paling lama 4 tahun; Setiap penyalah guna Narkotika Golongan II bagi diri sendiri dipidana dengan pidana penjara paling lama 2 tahun; dan Setiap penyalah guna Narkotika Golongan III bagi diri sendiri dipidana dengan pidana penjara paling lama 1 tahun."

Sanksi terhadap Penyalah Guna Narkotika telah di atur dalam Undang-Undang No. 35 Tahun 2009 tentang Narkotika telah mengatur jenis-jenis sanksi yang diberikan pada tindak pidana narkotika antara lain:

1. Tindak Pidana bagi penyalah guna atau sebagai korban Penyalah Guna narkotika, penyalah guna tersebut wajib menjalani rehabilitasi medis dan rehabilitasi sosial.

2. Tindak Pidana bagi Pecandu Narkotika yang Tidak Melaporkan Diri (Pasal 134) ayat (1), dipidana dengan pidana kurungan paling lama 6 (enam) bulan atau pidana denda paling banyak Rp2.000.000,00 (dua juta rupiah). ayat (2), dipidana dengan pidana kurungan paling lama 3 (tiga) bulan atau pidana denda paling banyakRp1.000.000,00 (satu juta rupiah). ${ }^{8}$

Dalam Undang-undang No.35 Tahun 2009, terdapat empat kategorisasi tindakan melawan hukum yang dilarang oleh undang-

${ }^{8}$ Hartato Pakpahan, I Nyoman Nurjaya, Nurini Aprilianda, "Kebijakan Formulasi Sanksi Tindakan Bagi Pengguna Dalam Tindak undang dan dapat diancam dengan sanksi pidana, yakni:

1. Kategori pertama, yakni perbuatanperbuatan berupa memiliki, menyimpan, menguasai atau menyediakan narkotika dan prekursor narkotika (Pasal 111 dan 112 untuk narkotika golongan I, Pasal 117 untuk narkotika golongan II dan Pasal 122 untuk narkotika golongan III serta Pasal 129 huruf (a));

2. Kategori kedua, yakni perbuatanperbuatan berupa memproduksi, mengimpor, mengekspor, atau menyalurkan narkotika dan precursor narkotika (Pasal 113 untuk narkotika golongan I, Pasal 118 untuk narkotika golongan II, dan Pasal 123 untuk narkotika golongan III serta Pasal 129 huruf(b));

3. Kategori ketiga, yakni perbuatanperbuatan berupa menawarkan untuk dijual, menjual, membeli, menerima, menjadi perantara dalam jual beli, menukar, atau menyerahkan narkotika dan prekursor narkotika (Pasal 114 dan Pasal 116 untuk narkotika golongan I, Pasal 119 dan Pasal 121 untuk narkotika golongan II, Pasal 124 dan Pasal 126 untuk narkotika golongan III serta Pasal 129 huruf(c));

4. Kategori keempat, yakni perbuatanperbuatan berupa membawa, mengirim, mengangkut atau mentransit narkotika dan prekursor narkotika (Pasal 115 untuk narkotika golongan I, Pasal 120 untuk narkotika golongan II dan Pasal 125 untuk narkotika golongan III serta Pasal 129 huruf(d)).

Namun pada perkembangan yang ada saat ini menunjukkan terjadinya kecenderungan perubahan kuat dalam

Pidana Narkotika, Fakultas Hukum Universitas Negeri Brawijaya 
memandang para pengguna Narkotika yang tidak lagi dilihat sebagai pelaku kriminal, namum sebagai korban atau pasien yang harus diberi empati. ${ }^{9}$ Di Indonesia sendiri sering para penyalah guna Narkotika hanya menjalani pengobatan dan/atau perawatan seperti di Rehabilitasi untuk beberapa waktu dan tidak mendapatkan sanksi sesuai dengan Undang-Undang No.35 Tahun 2009 pasal 27.

Penyalah guna Narkotika yang terjadi dikalangan legislative setiap tahunnya selalu ada dan terus bertambah. Seperti yang terjadi pada pada tanggal 22 Maret 2020, bahwa 2 anggota DPRD Boalemo ditanggkap akibat penggunaan Narkotika di Jakarta. Hal ini tentu membuat banyak masyarakat geram dan juga resah, para anggota legislative yang dipercaya sebagai wakil rakyat malah menyalahgunakan jabatan yang mereka miliki. Belum lagi kasus ini terjadi disaat pemerintah dan masyarakat sedang bersatu melawan Covid-19, pada saat yang bersamaan para oknum legislative ini hanya berpesta narkoba disebuah diskotik yang terletak di Jakarta. Menurut informasi dari situs berita Kronologi.id, sudah 14 hari pasca penetapan tersangka dugaan kasus narkoba yang melibatkan dua anggota DPRD boalemo di Jakarta, hingga tanggal 6 Maret 2020 partai Golkar dan PDI belum mengeluarkan sanksi tegas. ${ }^{10}$ Tentunya dengan penyalah guna narkotika yang dilakukan oleh para anggota legislative ini harus mendapat sanksi tegas dari pemerintah, seperti yang di atur dalam Undang-Undang No. 35 tahun 2009, juga harus dilakukan

9 Dani Krisnawaty dan Eddy O.S. Hiariej, Bunga Rampai Hukum Pidana Khusus, Jakarta: Pena Pundi Aksara, 2006, hal.99 10 https://kronologi.id/2020/04/06/2legislator-boalemo-terlibat-kasus-narkobabelum-terima-sanksi-dari-partainya/ pemecatan dan tidak dapat lagi menjadi anggota legislative.

\section{Kebijakan Kriminal yang Dilakukan Untuk Memberantas Penyalah Guna Narkotika di Kalangan Legislatif}

Sudarto mengemukakan tiga arti mengenai kebijakan criminal, yaitu: 11

1. Dalam arti sempit, adalah keseluruhan asas dan metode yang menjadi dasar dari reaksi terhadap pelanggaran hukum yang berupa pidana;

2. Dalam arti luas, adalah keseluruhan fungsi dari aparatur penegak hukum, termasuk di dalamnya cara kerja dari pengadilan dan polisi dan;

3. Dalam arti yang paling luas, adalah keseluruhan kebijakan yang dilakukan melalui perundangundangan dan badan-badan resmi, yang bertujuan untuk meneggak norma-norma sentral dari masyarakat.

Berdasarkan definisi diatas diperoleh gambaran bhawa kebijakan kriminal merupakan usaha yang rasional dari masyarakat untuk mencegah kejahaan dan mengadakan reaksi terhadap kejahatan. ${ }^{12}$

G. Peter Hoefnagels mengemukakan beberapa definisi mengenai kebijakan kriminal antara lain :

1. criminal policy is the science of response

2. crime policy is the science of prevention

3. crime polici is a policy of designating human behavior as crime

11 Barda Nawawi Arief, 2008, Bunga Rampai Kebijakan Hukum Pidana, Kencana Prenada Media Group, Jakarta, hlm.1

12 Repository.unisba.ac.id, hlm 17 
4. criminal policy is arational total of the response to crime. ${ }^{13}$

Istilah criminal policy yang dipergunakan oleh Hoefnagels bila diterjemahkan dalam bahasa Indonesia disebut sebagai "kebijakan kriminal". Istilah ini agaknya kurang pas karena seolah-olah mencari suatu kebijakan untuk membuat kejahatan (kriminal). Istilah ini lebih tepat digunakan sebagai kebijakan penanggulangan kejahatan. ${ }^{14}$

Dalam menjalankan kebijakan kriminal tentunya harus sesuai dengan struktur hukum. Menurut Friedman ditentukan oleh 3 unsur, yaitu struktur hukum, subtansi hukum, dan budaya hukum. ${ }^{15}$

Kebijakan atau upaya penanggulangan kejahatan pada hakikatnya merupakan bagian integral dari upaya perlindungan masyarakat (social defence) dan upaya mencapai kesejahteraan (social welfare). Kebijakan penanggulangan kejahatan atau bisa disebut juga politik kriminal memiliki tujuan akhir atau tujuan utama yaitu "perlindungan masyarakat untuk mencapai kesejahteraan masyarakat". Kebijakan penanggulangan kejahatan (criminal policy) itu sendiri merupakan bagian dari kebijakan penegakan hukum (law enforcement policy). Kebijakan penegakan hukum merupakan bagian dari kebijakan social (social policy) dan termasuk juga dalam kebijakan legislatif (legislative policy). Politik kriminal pada hakikatnya juga merupakan bagian integral dari kebijakan sosial yaitu kebijakan atau upaya untuk mencapai kesejahteraan sosial. ${ }^{16}$

13 Ibid, hlm. 17

14Mahmud Mulyadi, 2008, Criminal Policy: Pendekatan Integral Penal Policy dan Non Penal Policy dalam Penanggulangan Kejahatan Kekerasan, Pustaka Bangsa Press, Medan, hlm. 51.

15 Bahan-bahan Kuliah Politik hukum Pidana Fakultas Hukum USU tahun 2011
Kebijakan penegakan hukum (law enforcement policy) harus melihat cakupan yang luas yang terkandung dalam suatu sistem hukum (legal system). Menurut Friedman bahwa sistem hukum adalah memiliki cakupan yang lebih luas dari hukum itu sendiri. Kata "hukum" sering mengacu hanya pada aturan dan peraturan. Sedangkan sistem hukum membedakan antara aturan dan peraturan itu sendiri, serta struktur, lembaga dan proses yang mengisinya. Oleh karena itu, bekerjanya hukum di dalam suatu sistem menurut Friedman ditentukan oleh tiga unsur, yaitu struktur hukum (legal structure), substansi hukum (legal substance), dan budaya hukum (legal culture). ${ }^{17}$

Dari banyaknya penjelasan diatas dapat kita tarik kesimpulan bahwa kebijakan kriminal ini ada untuk menjadi langkah pencegahan untuk meneggak norma-norma sentral dari masyarakat.

Dalam hal pencegahan dikutip dari liputan6.com Presiden Joko Widodo telah menyatakan tidak akan memberi ampun bagi siapa saja yang terlibat, bahkan kejahatan narkoba telah ditetapkan sebagai kejahatan luar biasa. Namun jika hanya berdasar dari pernyataan tersebut tidak cukup untuk menakuti - nekuti para penyalahgunaan narkoba dalam hal ini adalah anggota DPRD. ${ }^{18}$

Untuk memuluskan misi memberantas kejahatan narkoba Jokowi mempunyai 5 langkah yang di anggap jitu olehnya:

1. Jokowi meminta pemerintah pusat dan dcaerah terus berkomunikasi dalam rangka penyelenggaraan program-

16 Barda Nawawi Arief, 2008, Bunga Rampai Kebijakan Hukum Pidana (Perkembangan Penyusunan Konsep KUHP Baru), Kencana Prenada Media Group, Jakarta, hlm. 1

17 Bahan - bahan Kuliah politik Hukum Pidana Fakultas Hukum USU Tahun 2011 18 Liputan6.com, Jakarta 2015 
program dan pelaksanaan penyalahgunaan penggunaan narkoba.

2. Peningkatan terapi dan rehabilitasi pecandu dan penyalahgunaan narkoba.

3. Mengimbau penegak hukum agar meningkatkan keberanian menghukum mereka yang terlibat.

4. Peningkatan pengawasan lembaga pemasyarakatan.

5. Kenali modus-modus peredaran baru dalam penyelundupan narkoba. ${ }^{19}$

5 langkah yang dipilih oleh Jokowi sudah dianggap bisa mengatasi dan menaanggulangi penyalahgunaan narkoba bisa dikatakan berjalan lumayan baik. Dalam laman resmi Badan Narkotika Nasioan (BNN) Republik Indonesia Tahun 2018 sendiri telaah menyebutkan bahwa 3,37 penduduk Indonesia yang terlibat dalam penyalahgunaan narkoba. Angka yang tak sedikit itu juga merupakan angka yang turun dari penelitian tahun 2014 sekitar 4 juta orang. 20 Dari banyaknya penduduk Indonesia yang terlibat juga dari berbagai kalangan, tak terkecuali anggota DPRD.

Dari beberapa kasus narkoba yang ditangani khsususnya yang melibatkan anggota DPRD berbeda - beda penyelesaian atau hukumannya.

Keberadaan Undang-Undang Narkotika yakni Undang-Undang No. 35 Tahun 2009 tentang Narkotika juga merupakan suatu upaya politik hukum pemerintah Indonesia terhadap penanggulangan tindak pidana narkotika. Pembentukan undang-undang narkotika diharapkan dapat menanggulangi peredaran gelap dan penyalahgunaan narkotika dengan menggunakan sarana hukum pidana atau penal. ${ }^{21}$

19 Ibid.

20 Badan narkotika Nasional (BNN) Republik Indonesia, 2018

\section{PENUTUP \\ Kesimpulan}

Dari hasil penelitian ini dapat disimpulkan bahwa narkotika yang awalnya berdampak positif sebagai obat namun sudah banyak digunakan dalam dosis yang salah sehingga dapat berbahaya oleh tubuh. Oleh karena itu pemerintah mengatur tentang penyalahgunaan tersebut. Penyalahgunaan narkotika sudah terjadi di berbagai kalangan mulai dari pelajar,mahasiswa,buruh,pekerja kantoran,pejabat tinggi Negara bahkan anggota legislative. Walaupun dalam Undang No. 35 Tahun 2009 tentang Narkotika telah mengatur kategoriasi penyalahgunaan narkoba dan sanksinya, namun masih ada saja yang melanggar.

\section{Saran}

Dengan adanya penelitian ini, diharapkan pemerintah lebih tegas lagi dalam menangani kasus penyalahgunaan narkotika,terutama pada anggota legislative. Karena walaupun jabatan mereka tinggi,namun di mata hukum semuanya sama. Dan alangkah baiknya untuk menimbulkan efek jera tiap anggota legislative yang terlibat dalam penyalahgunaan narkotika diberikan sanksi tambahan berupa pemecatan dan tidak dapat lagi mencalonkan diri sebagai anggota legislative di masa berikutnya. Hal tersebut agar meningkatkan kesadaran bahwa penggunaan narkotika yang tidak sesuai semestinya adalah salah

\section{DAFTAR PUSTAKA}

\section{Buku}

Abdulkadir Muhamad. 2004. Hukum dan Penelitian Hukum. Bandung: PT. Citra Aditya Bakti

Bahan-bahan Kuliah Politik hukum Pidana Fakultas Hukum USU

${ }^{21}$ ADIL: Jurnal Hukum Vol. 7 No.1 
Bambang Sunggono, 2016, Metodologi Penelitian Hukum, Rajawali Pers, Jakarta.

Barda Nawawi Arief, 2008, Bunga Rampai Kebijakan Hukum Pidana, Kencana Prenada Media Group, Jakarta

Dani Krisnawaty dan Eddy O.S. Hiariej, Bunga Rampai Hukum Pidana Khusus, Jakarta: Pena Pundi Aksara, 2006.

Jimly Asshiddiqie, Pengantar Ilmu Hukum Tata Negara, (Jakarta: PT. RajaGrafindo Persada, 2009).

Mahmud Mulyadi, 2008, Criminal Policy: Pendekatan Integral Penal Policy dan Non Penal Policy dalam Penanggulangan Kejahatan Kekerasan, Pustaka Bangsa Press, Medan

Mukti Fajar dan Yulianto Achmad, 2010, Dualisme Penelitian Hukum Empiris \& Normatif, Pustaka Pelajar.

SULAIMAN, S.H, Biro Hukum Provinsi kepulauan Bangka Belitung, (Kepulauan Bangka Belitung)

\section{Undang-Undang}

Pasal 7 Undang-undang No. 35 Tahun 2009

lampiran Undang-Undang Nomor 35 tahun 2009 tentang Narkotika

Undang-Undang No. 22 tahun 1997

Undang-Undang Nomor 35 tahun 2009 tentang Narkotika.

Undang-Undang Nomor 35 tahun 2009 tentang Narkotika.

UUD Negara Republik Inonesia tahun 1999

Undang-Undang Negara Republik Indonesi No.17 Tahun 2014

Pasal 1 angka 15 UU No.35 Tahun 2009

\section{Jurnal}

Endang Mulyatiningsih, Metode Penelitian terapan Bidang Pendidikan, CV Alfabeta :

Bandung, 2014
Depri Liber Sonata, "Metode Penelitian Hukum Normatif dan Empiris: Karakteristik Khas Dari Metode Meneliti Hukum", jurnal fiat justitia, vol.8, No.1, 2014

Fransiska Novita Eleanora, "Bahaya Penyalahgunaan Narkoba Serta Usaha Pencegahan dan Penanggulangannya (Suatu Tinjauan Teoritis), FH Universitas MPU Tantular Jakarta

Hartato Pakpahan, I Nyoman Nurjaya, Nurini Aprilianda, "Kebijakan Formulasi Sanksi Tindakan Bagi Pengguna Dalam Tindak Pidana Narkotika, Fakultas Hukum Universitas Negeri Brawijaya

ADIL: Jurnal Hukum Vol. 7 No.1

\section{Website}

KBBI: kbbi.web.id

https://kronologi.id/2020/04/06/2-

legislator-boalemo-terlibat-kasus-narkoba-

belum-terima-sanksi-dari-partainya/

liputan6.com 